\title{
Geographic Distribution of MERS Coronavirus among Dromedary Camels, Africa
}

\section{Chantal B.E.M. Reusken, ${ }^{1}$ Lilia Messadi, ${ }^{1}$ Ashenafi Feyisa, ${ }^{1}$ Hussaini Ularamu, ${ }^{1}$ Gert-Jan Godeke, Agom Danmarwa, Fufa Dawo, Mohamed Jemli, Simenew Melaku, David Shamaki, Yusuf Woma, Yiltawe Wungak, Endrias Zewdu Gebremedhin, Ilse Zutt, Berend-Jan Bosch, Bart L. Haagmans, and Marion P.G. Koopmans}

We found serologic evidence for the circulation of Middle East respiratory syndrome coronavirus among dromedary camels in Nigeria, Tunisia, and Ethiopia. Circulation of the virus among dromedaries across broad areas of Africa may indicate that this disease is currently underdiagnosed in humans outside the Arabian Peninsula.

novel betacoronavirus, Middle East respiratory synAdrome coronavirus (MERS-CoV), was identified as the cause of severe respiratory disease in humans during 2012 (1). In August 2013, dromedary camels (Camelus dromedarius) were implicated for the first time as a possible source for human infection on the basis of the presence of MERS-CoV neutralizing antibodies in dromedaries from Oman and the Canary Islands of Spain (2). Since then, the presence of MERS-CoV antibodies in dromedaries has been reported in Jordan (3), Egypt $(4,5)$, the United Arab Emirates (6,7), and Saudi Arabia (8,9). In October 2013, analysis of an outbreak associated with 1 barn in Qatar (10) found dromedaries and humans to be infected with nearly

Author affiliations: Netherlands Centre for Infectious Disease Control, Bilthoven, the Netherlands (C.B.E.M. Reusken, G.-J. Godeke, I. Zutt, M.P.G. Koopmans); Erasmus Medical Center, Rotterdam, the Netherlands (C.B.E.M. Reusken, B.L. Haagmans, M.P.G. Koopmans); National Veterinary Medicine School, University of La Manouba, Sidi Thabet, Tunisia (L. Messadi, M. Jemli); Addis Ababa University College of Veterinary Medicine and Agriculture, Bishoftu, Ethiopia (A. Feyisa, F. Dawo, S. Melaku, E. Z. Gebremedhin); National Veterinary Research Institute, Vom, Nigeria $(H$. Ularamu, A. Danmarwa, D. Shamaki, Y. Woma, Y. Wungak) and Faculty of Veterinary Medicine, Utrecht University, Utrecht, the Netherlands (B.-J. Bosch)

DOI: http://dx.doi.org/10.3201/eid2008.140590 identical strains of MERS-CoV. Further proof of widespread circulation of MERS-CoV among dromedaries was provided by studies from Egypt and Saudi Arabia $(5,9)$. These findings have raised questions about the geographic distribution of MERS-CoV among camel populations elsewhere. Here, we report our assessment of the geographic distribution of MERS-CoV circulation among dromedaries in Africa by serologic investigation of convenience samples from these animals in Nigeria, Tunisia, and Ethiopia.

\section{The Study}

In Nigeria, serum samples from 358 dromedaries that were raised for meat production were collected at abattoirs in 4 provinces (Kano, $\mathrm{n}=245$; Sokoto, $\mathrm{n}=51$; Borno, $\mathrm{n}$ = 51; and Adamawa, $\mathrm{n}=11$; Figure 1, panel A) during 2010-2011 for testing for peste des petits ruminants virus. The ages of the animals ranged from 4 to 15 years. The abattoirs also served the neighboring countries of Chad, Niger, and the Central African Republic. In Tunisia, serum samples from 204 dromedaries that were 1 to 16 years of age were collected in 3 provinces in 2009 and 2013 (Figure 1, panel B). Samples were collected from 155 dromedaries in Sidi Bouzid Province from 27 herds that were kept for meat production and from 39 dromedaries in Kebili Province from 16 herds that were kept for tourist rides; samples from both provinces had originally been collected for a study investigating the presence of Anaplasma phagocytophilum. Samples were collected from 10 dromedaries from Sousse Province that were kept for meat production because they were suspected of being infected with Trypanosoma evansi. In Ethiopia, samples from 188 dromedaries, 1 to 13 years of age, were collected as part of a study evaluating the presence of toxoplasmosis and respiratory tract diseases in 3 provinces (Afar, $\mathrm{n}=118$; Somalia, $\mathrm{n}=11$; and Oromia, $\mathrm{n}=$ 59; Figure 1, panel C) during 2011-2013. All samples were taken by jugular vein puncture according to local laws, and serum samples were stored at $-20^{\circ} \mathrm{C}$ until testing. All serum samples were shipped to the Erasmus MC laboratory in the Netherlands in agreement with Dutch import regulations.

The serum samples were tested for the presence of IgG antibodies reactive with $\mathrm{S} 1$ antigens against MERS-CoV (residues 1-747), severe acute respiratory syndrome $\mathrm{CoV}$ (residues 1-676), and human CoV OC43 (residues 1-760) by using extensively validated protein-microarray technology, as described $(2,3,6,11)$. Results were expressed as relative mean fluorescent intensity (RFU) for each set of quadruplicate spots of antigen, with a cutoff of 4,000 RFU as used by Meyer et al. (6). Human CoV OC43 S1 was used as a proxy for bovine coronavirus (BCoV), the latter of which is known to circulate commonly in dromedaries $(7,12)$. High percentages of animals seropositive

${ }^{1}$ These authors contributed equally to this article. 


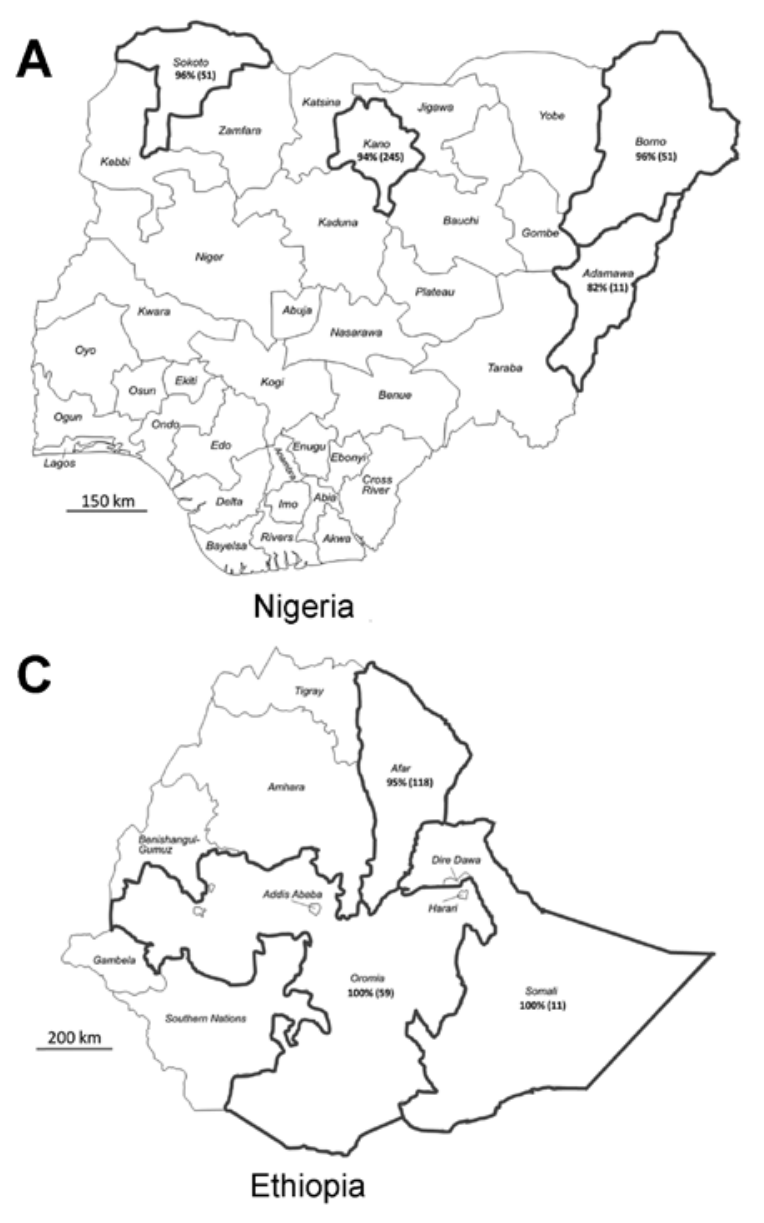

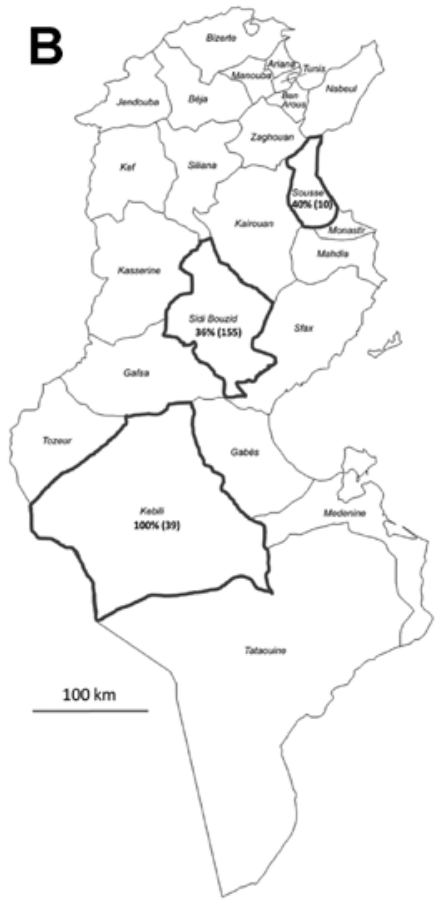

Tunisia
Figure 1. Countries and provinces sampled in this study: A) Nigeria, B)Tunisia, and C) Ethiopia. Black outline indicates provinces in which samples were collected. Serologic results are indicated in each province as percentage seropositive for Middle East respiratory syndrome coronavirus (total no. dromedaries tested). Maps adapted from http://d-maps. com/index.php for MERS-CoV were observed in Nigeria and Ethiopia; the overall seropositivity was $94 \%$ in adult dromedaries in Nigeria and $93 \%$ and $97 \%$ for juvenile and adult animals, respectively, in Ethiopia (Table 1). All provinces in which dromedaries were sampled in both countries showed high rates of seropositivity (Figure 1). The overall seropositivity in dromedaries in Tunisia was $30 \%$ for animals $\leq 2$ years of age and $54 \%$ for adult animals. Seropositivity of $36 \%$ and $40 \%$ was observed in Sidi Bouzid and Sousse Provinces, respectively, and $100 \%$ of the dromedaries in the southern province of Kebili were seropositive. Array results were confirmed on a selection of positive and negative serum samples $(\mathrm{n}=14$ per country) in MERS-CoV neutralization tests performed as described (2) (Table 2). Serum samples from $72 \%, 82 \%$, and $67 \%$ of the dromedaries from Nigeria, Ethiopia, and Tunisia, respectively, reacted with the OC43 antigen, confirming common circulation of $\mathrm{BCoV}$ in camelids $(7,12)$. All samples tested negative for severe acute respiratory syndrome $\mathrm{CoV}$ (data not shown).

\section{Conclusions}

Since the discovery of MERS-CoV in 2012, accumulating serologic and molecular evidence demonstrates that the virus in dromedaries is genetically very similar to MERS-CoV in humans and points to the conclusion that dromedary camels are reservoirs for human infection. MERS-CoV genomic fragments have been detected in dromedaries in Qatar (10) and Saudi Arabia (9); near full-genome sequences have been generated from dromedaries in Egypt (5) and full-genome sequences have been generated from dromedaries in Saudi Arabia (13). Here, we show serologic evidence for circulation of MERS-CoV or MERS-like $\mathrm{CoV}$ in dromedaries in countries in East, West, and North Africa, with possible herd-specific differences in prevalence in Tunisia. The lower seropositivity observed in herds raised for meat production in Tunisia might reflect a high turnover of camels with a continuous introduction of animals unexposed to the MERS-CoV into these herds. No camels imported from neighboring countries were found at the meat-producing farms in Sidi Bouzid and Sousse, only camels purchased from other farms in the same area or other areas in Tunisia. However, animals are frequently moved between Libya and Kebili for trade.

Samples in this study were collected during 20092011, confirming observations by us and others (6) that the virus circulated well before March 2012, which is the 
Table 1. Overview of serologic evidence for Middle East respiratory syndrome coronavirus among dromedary camels, Africa and the Arabian Peninsula

\begin{tabular}{|c|c|c|c|c|}
\hline Country & Year & No. camels* & $\begin{array}{l}\text { dle East respiratory syno } \\
\text { coronavirus antibodies }\end{array}$ & Reference \\
\hline \multirow[t]{3}{*}{ United Arab Emirates } & 2013 & $500(A, J)$ & $96+, \mp, \S, \mathbb{I}$ & (6) \\
\hline & 2013 & $59(\mathrm{~A})$ & $97 \#, 100^{* *}, 98 \S$ & (7) \\
\hline & 2003 & $151(\mathrm{~A})$ & $100 \ddagger, \S$ & (6) \\
\hline \multirow[t]{2}{*}{ Egypt } & 2013 & $110(\mathrm{~A})$ & 94§, 98†† & (4) \\
\hline & 2013 & $17(\mathrm{~A})^{\prime}$ & $82+\dagger$ & (5) \\
\hline \multirow[t]{2}{*}{ Spain (Canary Islands) } & 2012-2013 & $97(\mathrm{~A})$ & $14 \S, \rrbracket$ & (2) \\
\hline & 2012-2013 & $8(\mathrm{~J})$ & $13 \S, \pi$ & (2) \\
\hline \multirow[t]{2}{*}{ Ethiopia } & 2010-2011 & $31(\mathrm{~J})$ & $93 \pi$ & This study \\
\hline & 2010-2011 & $157(\mathrm{~A})$ & $97 \pi$ & This study \\
\hline \multirow{2}{*}{ Ethiopia, Sudan } & 2013 & $35(\mathrm{~A})$ & $97 \dagger \dagger$ & (5) \\
\hline & 2013 & $11(\mathrm{~J})$ & $100 \S, \pi$ & (3) \\
\hline Nigeria & $2010-2011$ & $358(\mathrm{~A})$ & $94 \pi$ & This study \\
\hline Oman & 2013 & $50(A)$ & $100 \S, \rrbracket$ & (2) \\
\hline Qatar & 2013 & $14(\mathrm{~A})$ & $100 \S, \pi$ & (10) \\
\hline \multirow[t]{13}{*}{ Saudi Arabia } & $2010-2013$ & $65(\mathrm{~J})$ & $72 \dagger \dagger$ & $(8)$ \\
\hline & 2010-2013 & $245(\mathrm{~A})$ & 95†† & (8) \\
\hline & 2013 & $104(\mathrm{~J})$ & 55市 & (9) \\
\hline & 2013 & $98(A)$ & 95ł‡ & (9) \\
\hline & 2010 & $21(\mathrm{~J})$ & 76拉 & (9) \\
\hline & 2010 & $23(\mathrm{~A})$ & 91辝 & (9) \\
\hline & 2009 & $56(\mathrm{~J})$ & $72 \ddagger \ddagger$ & (9) \\
\hline & 2009 & $26(\mathrm{~A})$ & $92 \ddagger \ddagger$ & (9) \\
\hline & 2004 & $6(A)$ & $100 \ddagger \ddagger$ & (9) \\
\hline & 1996 & $6(\mathrm{~A})$ & $100 \ddagger \ddagger$ & (9) \\
\hline & 1994 & $123(\mathrm{~A})$ & $93 \neq \ddagger$ & (9) \\
\hline & 1993 & $2(\mathrm{~A})$ & $100 \ddagger \ddagger$ & (9) \\
\hline & 1992 & $1(\mathrm{~A})$ & $100 \ddagger \ddagger$ & (9) \\
\hline \multirow[t]{2}{*}{ Tunisia } & 2009 & $46(\mathrm{~J})$ & $30 \pi$ & This study \\
\hline & 2009 & $158(\mathrm{~A})$ & $54 \pi$ & This study \\
\hline \multicolumn{5}{|c|}{$\begin{array}{l}\text { *Camel age range indicated where known. J, juvenile } \leq 2 \text { y of age } \\
\text { †Determined by recombinant spike immunofluorescence assay. } \\
\text { †Determined by neutralization test. } \\
\text { §Determined by nucleocapsid western blot. } \\
\text { TDetermined by } \$ 1 \text { micro-array. } \\
\text { \#Determined by whole virus IFA. } \\
\text { **Determined by pseudoparticle neutralization test. } \\
\text { t+Determined by complete virus infected cell ELISA. }\end{array}$} \\
\hline
\end{tabular}

estimated time of identification of the most common ancestor for the MERS-CoV strains found in humans to date (14). The earliest serologic indication for circulation of MERS$\mathrm{CoV}$ or MERS-like $\mathrm{CoV}$ in dromedaries was observed in 1992; however, this result was based on results of a wholevirus ELISA with undescribed specificity (9). On the basis of well-validated array and neutralization tests, the study of dromedaries in the United Arab Emirates showed the presence of MERS-CoV or MERS-Cov-like antibodies as early as 2003 (6). The accumulated data on MERS-CoV serology in dromedaries (Figure 2; Table 1) show circulation of MERS-CoV or MERS-like $\mathrm{CoV}$ in dromedaries in Africa and the Arabian Peninsula well before 2012, when the first cases in humans were identified, and show overall high levels of seropositivity, including in animals from countries without reported human cases.

A question raised by these findings is whether human cases occur outside the Arabian Peninsula and if such cases are currently underdiagnosed in Africa. In addition, for the whole region, the possibility exists that MERS-CoV illness occurred before its discovery in 2012 and that such infection has been overlooked in the areas with evidence for virus circulation among animals during the past 10 years. Retrospective studies of cohorts of humans with respiratory illnesses of unknown etiology should address this notion.

Alternative explanations for the lack of cases in Africa could be the following: a different risk profile, for instance, related to demographics and local practices; or subtle genetic differences in the circulating virus strain. Full-genome sequencing, virus isolation, and phenotypic characterization of viruses circulating outside the Arabian Peninsula will resolve this issue. Meanwhile, awareness of MERS-CoV infections should be raised among clinicians in Africa.

\section{Acknowledgments}

We thank Lotfi Sayahi from Tunisia for collecting samples within the framework of his dissertation of veterinary medicine within the research laboratory, funded by the $\mathrm{Tu}$ nisian Ministry of Higher Education and Research. We also thank C. van Maanen and C. Gortazar-Schmidt for establishing contact between this research group and researchers in Nigeria and Tunisia. 
MERS among Dromedary Camels, Africa

Table 2. Background data and Middle East respiratory syndrome coronavirus serology results of selected camel serum samples from Nigeria, Ethiopia, and Tunisia*

\begin{tabular}{|c|c|c|c|c|c|c|c|}
\hline Country, sample ID & Region & Age & Sex & MERS S1 (1:20) & MERS S1 (1:320) & MERS S1 (1:640) & VNT \\
\hline \multicolumn{8}{|l|}{ Nigeria } \\
\hline 1 & Kano & 7 & $\mathrm{M}$ & 63410 & 52,254 & NT & 640 \\
\hline 2 & Kano & 2 & $\mathrm{~F}$ & 63,022 & 10,998 & 4,585 & 320 \\
\hline 3 & Adamawa & 6 & $M$ & 63,146 & 41,200 & 20,627 & 1,280 \\
\hline 4 & Kano & 2 & $M$ & 63,213 & 63,331 & 63,353 & 1,280 \\
\hline 5 & Sokoto & 2 & $\mathrm{~F}$ & 63,123 & 8,215 & - & 80 \\
\hline 6 & Borno & 7 & $M$ & 63,173 & 13,873 & 7,471 & 160 \\
\hline 7 & Borno & 6 & $\mathrm{~F}$ & 63,065 & 63,065 & NT & 2,560 \\
\hline 8 & Sokoto & 7 & $\mathrm{~F}$ & 64,118 & 63,285 & 54,669 & 640 \\
\hline 9 & Borno & 6 & $M$ & 63,592 & 28,033 & NT & 80 \\
\hline 10 & Sokoto & 6 & $\mathrm{~F}$ & 64,176 & 63,427 & 35,190 & 640 \\
\hline 11 & Sokoto & 2 & $\mathrm{~F}$ & - & NT & NT & $<20$ \\
\hline 12 & Adamawa & 7 & $M$ & - & NT & NT & $<20$ \\
\hline 13 & Unknown & 7 & $M$ & - & NT & NT & $<20$ \\
\hline 14 & Kano & 7 & $M$ & - & NT & NT & $<20$ \\
\hline \multicolumn{8}{|l|}{ Ethiopia } \\
\hline 1 & Somali & 5 & $\mathrm{~F}$ & 63,592 & 63,357 & 50,563 & 640 \\
\hline 2 & Afar & 6 & $\mathrm{~F}$ & 63,341 & 63,005 & NT & 2,560 \\
\hline 3 & Afar & 13 & $\mathrm{~F}$ & 63,366 & 63,205 & 63,467 & 1,280 \\
\hline 4 & Afar & 10 & $\mathrm{~F}$ & 63,206 & 63,299 & NT & 640 \\
\hline 5 & Afar & 5 & $\mathrm{~F}$ & 63,466 & 10,583 & 5,911 & 160 \\
\hline 6 & Fentale & $<4$ & $M$ & 63,408 & 63,480 & 60,135 & 1,280 \\
\hline 7 & Afar & 4 & $\mathrm{~F}$ & 63,476 & 33,909 & 19,161 & 80 \\
\hline 8 & Afar & 4 & $\mathrm{~F}$ & - & NT & NT & $<20$ \\
\hline 9 & Afar & 2 & $M$ & - & NT & NT & $<20$ \\
\hline 10 & Afar & 1 & $\mathrm{~F}$ & 10,937 & NT & NT & $<20$ \\
\hline 11 & Afar & 3 & $\mathrm{~F}$ & 18,269 & NT & NT & $<20$ \\
\hline 12 & Fentale & $>8$ & $\mathrm{~F}$ & 63,486 & 23,654 & 10,246 & 1,280 \\
\hline 13 & Afar & 6 & $\mathrm{~F}$ & 63,496 & 63,380 & 53,030 & 1,280 \\
\hline 14 & Afar & 1 & $\mathrm{~F}$ & 63,401 & 19,087 & 9,834 & 80 \\
\hline \multicolumn{8}{|l|}{ Tunisia } \\
\hline 1 & Sidi Bouzid & 8 & $\mathrm{~F}$ & - & NT & NT & $<20$ \\
\hline 2 & Sidi Bouzid & 8 & $\mathrm{~F}$ & 63,217 & 20,620 & NT & 80 \\
\hline 3 & Sidi Bouzid & 6 & $\mathrm{~F}$ & - & NT & NT & $<20$ \\
\hline 4 & Sidi Bouzid & 1 & $M$ & - & NT & NT & $<20$ \\
\hline 5 & Kebili & 7 & $M$ & 63,139 & - & - & 320 \\
\hline 6 & Kebili & 4 & $M$ & 63,113 & - & - & 160 \\
\hline 7 & Sidi Bouzid & 1 & $\mathrm{M}$ & - & NT & NT & $<20$ \\
\hline 8 & Sidi Bouzid & 9 & $\mathrm{~F}$ & 63,005 & 17,821 & 9,652 & 80 \\
\hline 9 & Sidi Bouzid & 6 & $\mathrm{~F}$ & - & NT & NT & $<20$ \\
\hline 10 & Kebili & 4 & $M$ & 63,120 & 18,320 & 9,732 & 160 \\
\hline 11 & Sidi Bouzid & $<1$ & $\mathrm{M}$ & - & NT & NT & $<20$ \\
\hline 12 & Sidi Bouzid & 2 & $\mathrm{~F}$ & 63,060 & 63,236 & 63,366 & 2,560 \\
\hline 13 & Sousse & 13 & $\mathrm{~F}$ & 63,220 & 50,510 & 26,575 & 320 \\
\hline 14 & Sidi Bouzid & 5 & $\mathrm{~F}$ & - & NT & NT & $<20$ \\
\hline
\end{tabular}

*MERS S1, Middle East respiratory syndrome coronavirus S1 micro-array. Serum dilutions tested 1:20, 1:320 or 1:640. Results expressed as relative mean fluorescent intensity (RFU) for each set of quadruplicate spots of antigen, with a cutoff of 4,000 RFU and $>63.000$ RFU as saturation signal; VNT, virus neutralization test (highest neutralizing serum dilution indicated); NT, not tested; -, negative.

Sample collection in Ethiopia was funded by a thematic research grant for Animal Health Improvement by Addis Ababa University, the Office of the Vice President for Research and Technology Transfer. B.H. was funded by the European Union FP7 project EMPERIE (contract number 223498), and M.K. was funded by the European Union FP7 project ANTIGONE (contract number 278976).

Dr Reusken is a public health virologist at the Viroscience Department of Erasmus Medical Center, Rotterdam, the Netherlands. Her research interests include viruses operating at the animal-human interface.

\section{References}

1. Zaki AM, van Boheemen $\mathrm{S}$, Bestebroer $\mathrm{TM}$, Osterhaus $\mathrm{AD}$, Fouchier RA. Isolation of a novel coronavirus from a man with pneumonia in Saudi Arabia. N Engl J Med. 2012;367:1814-20. http://dx.doi.org/10.1056/NEJMoa1211721

2. Reusken CB, Haagmans BL, Muller MA, Gutierrez C, Godeke GJ, Meyer B, et al. Middle East respiratory syndrome coronavirus neutralising serum antibodies in dromedary camels: a comparative serological study. Lancet Infect Dis. 2013;13:859-66. http://dx.doi.org/10.1016/S1473-3099(13)70164-6

3. Reusken CB, Ababneh M, Raj VS, Meyer B, Eljarah A, Abutarbush S, et al. Middle East Respiratory Syndrome coronavirus (MERS-CoV) serology in major livestock species in an affected region in Jordan, June to September 2013. Euro Surveill. 2013;18:20662. 


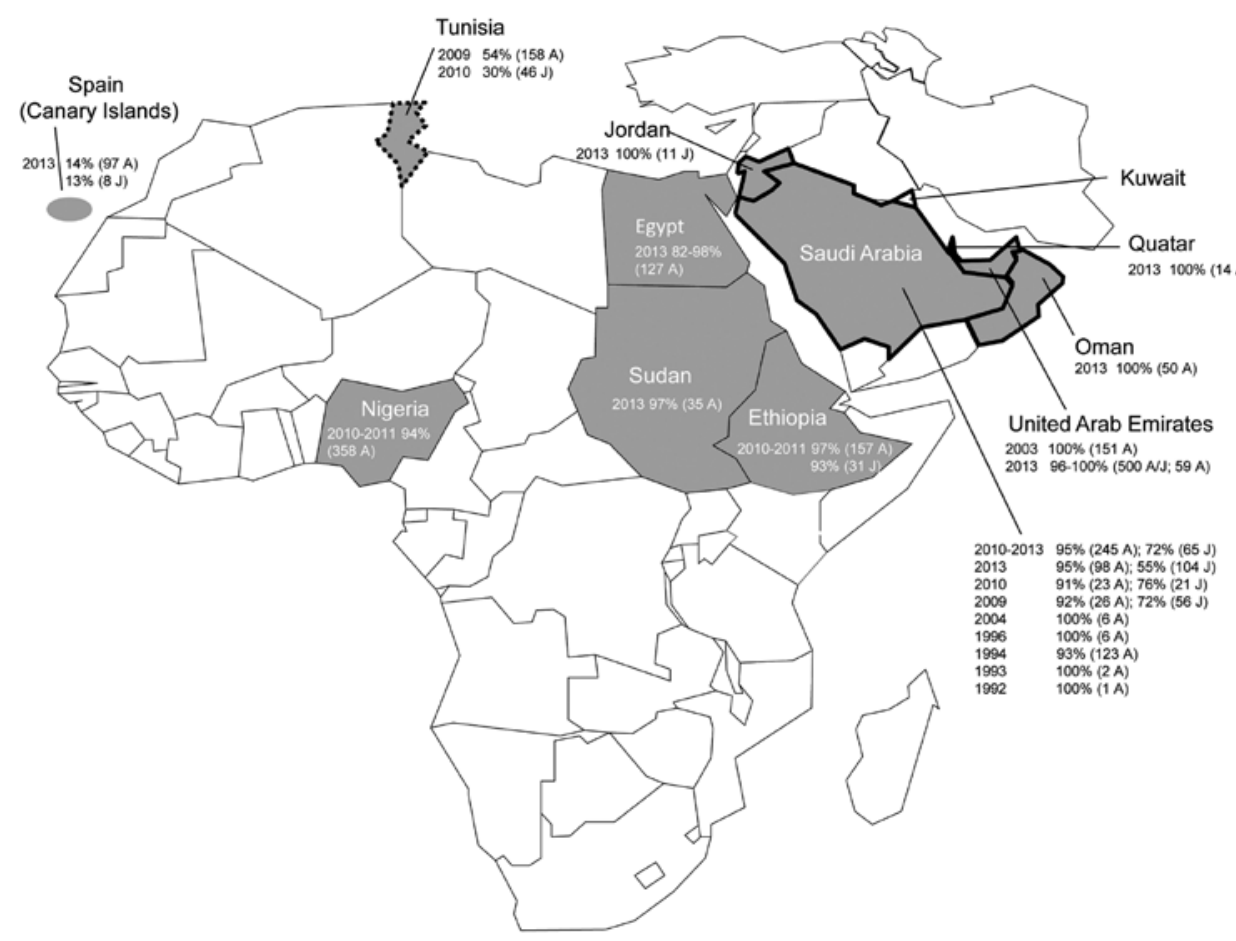

Figure 2. Geographic distribution of serologic evidence for Middle East respiratory syndrome coronavirus (MERS-CoV) or MERS-like CoV circulation in dromedaries in Africa and the Arabian Peninsula. Gray shading indicates countries with seropositive dromedaries; solid black outline indicates countries with primary human cases; dotted outline indicates countries with secondary human cases. For each country with affected dromedaries, the year of sampling, \% seropositive, total number tested, and age group are indicated. A, adult, $>2$ years of age; $\mathrm{J}$, juvenile, $\leq 2$ years of age. Details on serologic tests used and references are in Table 1.

4. Perera RA, Wang P, Gomaa MR, El-Shesheny R, Kandeil A, Bagato $\mathrm{O}$, et al. Seroepidemiology for MERS coronavirus using microneutralisation and pseudoparticle virus neutralisation assays reveal a high prevalence of antibody in dromedary camels in Egypt, June 2013. Euro Surveill. 2013;18:20574.

5. Chu DKW, Poon LLM, Gomaa MM, Shehata MM, Perera RAPM, Zeid DA, et al. MERS coronaviruses in dromedary camels, Egypt. 2014 [cited 20141 March]; http://dx.doi. org/10.3201/eid2006.140299

6. Meyer B, Müller MA, Corman VM, Reusken CBEM, Ritz D, Godeke GJ, et al. Antibodies against MERS coronavirus in dromedary camels, United Arab Emirates, 2003 and 2013. Emerg Infect Dis. 2014;20:552-9. http://dx.doi.org/10.3201/eid2004.131746

7. Woo PCY, Lau SKP, Wernery U, Wong EYM, Tsang AKL, Johnson B, et al. Novel betacoronavirus in dromedaries of the Middle East. Emerg Infect Dis. 2014;20:560-72. http://dx.doi. org/10.3201/eid2004.131769

8. Hemida MG, Perera RA, Wang P, Alhammadi MA, Siu LY, Li M, et al. Middle East Respiratory Syndrome (MERS) coronavirus seroprevalence in domestic livestock in Saudi Arabia, 2010 to 2013. Euro Surveill. 2013;18:20659.

9. Alagaili AN, Briese T, Mishra N, Kapoor V, Sameroff SC, de Wit E, et al. Middle East respiratory syndrome coronavirus infection in dromedary camels in Saudi Arabia. MBio. 2014;5(2). http://dx.doi. org/10.1128/mBio.00884-14
10. Haagmans BL, Al Dhahiry SH, Reusken CB, Raj VS, Galiano M, Myers R, et al. Middle East respiratory syndrome coronavirus in dromedary camels: an outbreak investigation. Lancet Infect Dis. 2014;14:140-5. http://dx.doi.org/10.1016/S14733099(13)70690-X

11. Reusken C, Mou H, Godeke GJ, van der Hoek L, Meyer B, Muller MA, et al. Specific serology for emerging human coronaviruses by protein microarray. Euro Surveill. 2013;18:20441.

12. Wünschmann A, Frank R, Pomeroy K, Kapil S. Enteric coronavirus infection in a juvenile dromedary (Camelus dromedarius). J Vet Diagn Invest. 2002;14:441-4. http://dx.doi. org/10.1177/104063870201400518

13. Hemida MG, Chu DKW, Poon LLM, Perera RAPM, Alhammadi MA, Ng H-Y, et al. MERS coronavirus in dromedary camel herd, Saudi Arabia. Emerg Infect Dis [Internet]. 2014 Jul [date cited]. http://dx.doi.org/10.3201/eid2007.140571

14. Cotten M, Watson SJ, Zumla AI, Makhdoom HQ, Palser AL, Ong SH, et al. Spread, circulation, and evolution of the Middle East respiratory syndrome coronavirus. MBio. 2014;5. http://dx.doi. org/10.1128/mBio.01062-13

Address for correspondence: Chantal B.E.M. Reusken, Erasmus MC, Viroscience; PO Box 2040, Rotterdam 3000 CA, Netherlands; email: c.reusken@erasmusmc.nl

\section{Manage your email to focus on content of interest to you.}

